\author{
N. Ichanska, Yu. Podoshvelev, O. Smitskiy, K. Rybachenko \\ Poltava National Technical Yuri Kondratyuk University, Poltava, Ukraine \\ Poltava National V.G. Korolenko Pedagogical University, Poltava, Ukraine
}

\title{
A QUALITY SELECTION OF SOFTWARE TO BUILD A SERVICE OF ELECTRONIC EQUIPMENT SALES
}

\begin{abstract}
Subject of the study in the article is an explanation of the method of selecting software tools and an example of their use for creating an e-shop, the basis for creating easy-to-use and methods to avoid obvious disadvantages of such services. Results - with emphasis on the qualitative selection of software tools which depend on the convenience of the service being created, namely: content management system, hypertext markup language, database management systems. The most used and productive software tools are considered and their advantages and disadvantages are explained, shown as the correct choice of software tools influences the flexibility of development on the example. An algorithm for creating an online store is presented. The main issues that may arise when creating a content management panel for the administrator and when using the service for potential buyers are described. An option to overcome these problems is suggested by using the WordPress content management system and constructing a linear use of the site. Conclusion - the method allows to provide competing opportunities in the administration of the service, in the flexibility and simplicity of its development, rational choice of resources and methods used, while not creating a separate admin panel to manage the content of the online store.
\end{abstract}

Keywords: software tools, online store, content management system, WordPress, databases, hypertext markup language, database management system, competitiveness, development methods.

\section{Introduction}

At the modern level of development of technologies there is a huge number of the Internet shops which have the advantages and shortcomings. Usually, such decisions are based on PHP, UI2, JS, AngularJS .NET. A lack of such websites, is the fact that for adding goods it is necessary to create additional functionality.

Analysis of a problem and problem definition. The task as much as possible to simplify development of such websites is urgent. They have to own the convenient interface, the simplified system of service and the reduced cost. It can be made by means of HTML as language of a hypertext marking and WordPress as a content management system [1-5].

It is necessary for untying of this task: to investigate the market of the Internet shops; to find their faults and benefits; to explain the choice of content management systems; to analyse point by point the sequence of work on the website $[6,7]$.

The solution of this task gives the chance to develop the Internet shop, management of which happens to the help of a panel in WordPress.

The work purpose - to describe a method of the choice of the software for the effective development of the Internet shop with the convenient interface simplified by system of service and reduced by cost.

During the course of performance this work the following tasks are solved:

1) the market of the Internet shops is investigated;

2) their faults and benefits are found;

3) recommendations about the choice of the software are provided;

4) the algorithm of work with services is given.

Practical result of work are recommendations concerning development of program service for sale of the electronic equipment, management, adding, removal of categories or goods, editing their description, cost and characteristics.

\section{Statement of the main material}

That the Internet shop was popular and had demand, it is necessary to make it clear for the user, easily accessible and attractive. It is necessary to attach all efforts that the user had no problems with the order of goods because it can otpugat it as the potential buyer. Output - the Internet shop has to be ideal to be popular and to make profit.

The ideal Internet shop is:

1. Linear order of actions. Steps within "steps" confuse, push away the buyer. Common example: the sentence to specify "a desirable delivery address" or "to create an accounting record" on the separate page. Then the user is redirected on the previous stage of registration of purchase from where it, roughly speaking, "pulled out" for filling of additional forms. It is important to understand that the mental model of most of buyers provides a consecutive set of actions. Having twice seen the same page, the person is lost and comes to a conclusion that there was an error, or through his fault ("I made something wrong"?), or because of technical faults of the website. To reach linear process, it is enough to direct the user to the following step. It should not be returned before from what having started!

2. Are clear to the description of a field of a form. Sample descriptions of fields of a form can be ambiguous. That the ordinary buyer has to think, having seen the following: "Enter the payment address". What? What address? What do you want from me?! Most often users do not understand what information type interests the Internet shop. Enter in a search line of Google a request "the payment address" and be convinced. Problems with understanding - a powerful argument to refuse purchase.

It is necessary to accompany each field of a form with the accurate, short description, and in certain cases an example. In liquid cases even the usual point "e-mail address" demands explanations - as it will be used 
further. For example, it is possible to specify that to e mails will come news about future events, etc. As not all users experience similar difficulties, once the instruction hides behind an icon in the form of a question mark or behind the link with the dropping-out text. Technical candidate solutions of this problem more than are enough.

3. Failure from use of contextual words. Treat them "to continue", "further", "back", "to apply", another. Value of these words changes depending on a context. On the page with a basket of goods the continue button means one or the other:

- the choice of goods (we will tell, to find a shirt to these wonderful jeans)

- to issue the order (the buyer with a basketful of goods is already ready to become the happy owner of a shirt and one pair of trousers).

Button "back". Back to search results of goods in the directory? To return to the previous page? To pass to main? These examples clearly demonstrate as contextual words which contents are open for interpretation bring to misunderstanding. Use words which do not change from the page to the page: "to continue the choice of goods", "to pass for payment".

4. Visual confirmation of safety. Its users do not think of safety exactly by that moment when it is necessary to enter payment details. Examinees them doubts can be characterized the phrase "it does not look safely". Yes, for the ordinary user there is no essential difference between mental model of safety and the actual safety. That is, the user will feel more surely if design, form elements, as well as the website in general, install trust. Specially picked up elements of page border, field of a form, icon, icons (the most widespread - the lock), another belong to visual security signals.

5. The form of registration/order placement has to consist of one column. Irrespective of the size of the monitor of the ultimate user, many forget to fill or just do not see the second column of a form. As a rule, only the left column then the user faces the error warning message and a persistent request is filled to fill the passed form fields.

6. Use of the address for drawing of the account, as delivery addresses behind concealing. Most of buyers shop in the Internet shops of the house. If it occurs in working hours, then for delivery to goods the home address all the same is specified. Thus, there is a sense to reduce quantity of fields due to connection of the payment detail and the destination. Also it will reduce probability of the wrong introduction of information and effects: if there was an introduced error, then it is necessary to correct it only in one place.

7. Accurate the instruction on an error source. When the buyer faces a problem when filling the order form, failure probability from purchase considerably grows. At $50 \%$ of cases need to independently look for a cause of error or to understand the error message which abounds with technical obscure terms, forces the client to leave the website. The error message can be displayed over upper limit of a form though it would be more correct to show warning in close proximity to a line where there was infed information. It is necessary not only point to an error, but also to provide to the user the instruction for its elimination. Therefore, warning has to have clear, accurate information, be selected, evident (it can be reached contrast and visual indicators).

8. Optional registration. What is the target audience of any online store? These are the modern people who are perfectly informed on such instrument of marketing as e - mail mailing. Almost each website with obligatory registration suggests to be signed for receiving news and other material of advertizing character. Without suspecting anything the user leaves the e-mail address and exactly the countdown from this point begins. How quickly it will place correspondence in the Spam folder? Very quickly. Than more often mailing - the highest chances comes.

The accounting record on the Internet as the admission - it opens all doors. A problem of each active user - a large number of admissions. Therefore the requirement to undergo registration on duty causes irritation, the it is more, so far as concerns spontaneous purchase. Besides, it takes away time and creates obstacles. There is only one decision - unostentatious service. The buyer has to have an option.

Technically it is solved thus. Suggest to be registered on completion of purchase. "You want to create an accounting record? Just enter the desirable password. As login it will be used earlier e - mail is specified by you". Watch how it is simple! Any excess steps, obligations. The buyer is not obliged to create the account, but has an opportunity to make it after purchase. It is it is clear, necessary to list benefits of existence of an accounting record.

9. Lack of demand for excess data. The more expensive order, the more information tells about themselves clients, but it is justified only if personal data of the user are a necessary condition for purchase. For example, phone number. Where logic? Means for communication was already noted (e - mail). If information superfluous in certain cases nevertheless is necessary, at least, explain why. What is obvious to the owner of shop is unevident for the client. The accurate explanation ("phone is necessary for communication with the client in case of problems with delivery") removes any questions and suspicions.

After determination with bases of a yuzabelnost of the website we suggest to deal with what needs to be used for its development and as to do it. The first that is necessary for creation of a visual part of the website - it is language of a hypertext marking. It is for this purpose reasonable to use HTML.

As a content management system we recommend popular WordPress. WordPress is a content management system with the open code. By means of this system it will be possible to add new goods and to direct already added and many another. Let's note that development of a template of the website shall be the first step for creation of the Internet shop. The homepage of the website is the menu which will orient the user on types of goods which attract its interest and it has desire to purchase goods from it. Having selected a certain category, the website has to readdress the user on goods of category which was elected by him. On the page there have to be filters and an opportunity to sort goods 
by certain parameters. Having selected goods before purchase, the user it will be readdressed on the page with a basket of goods for their order. The second step is connection of a template to a content management system above the mentioned WordPress. For this purpose it is necessary to create the account of the administrator for the database and to create the database. The administrator will work with it, that is to add goods and to edit данні about them. Also WordPress gives the chance to create filtering and sorting of goods. Why so popular Wordpress? To find out it, we will carry out the small analysis of this CMS. Therefore, work with the Wordpress system begins with its installation on the website. If the website is already placed on a hosting, then and the archive with the Wordpress distribution kit needs to be unpacked at once in the folder of the website which is on the server.

If the website meanwhile is on the local computer, then for work from Wordpress it is required to establish and configure previously the software - the local server (for example, SCO OpenServer) and SKBD (for example, MySQL) or already ready packet, for example Denwer. At what, for the WordPress installation the web hosting (or the local server) has to support PHP version 4.3 or above and MySQL of version 4.0 or above.

Using the MySQL control bar, it is necessary to create the database for Wordpress so that the user of MySQL had all access rights to this base.

The following step it is necessary to rename the wp file - config - sample.php into wp - config.php and to make changes to this file - to enter the user name of the database and the password. It is possible to make these changes in two ways. The first is to open the wp file - config.php by means of a text editor (for example, a notepad) and to manually register all settings. Or the second method - to register a way to the wp file in a line of the browser - config.php and to adhere to instructions. For access to management of the website to Wordpress it is necessary to prescribe in a line of the browser a way "to http://_m'ya website/wp - login.php" - and you will get to an administrator panel.

The administrator Wordpress panel is a special control bar which contains several sections.

The section "Write" allows to create new record or the separate page. This record can be published at once or to save and publish later.

In the section of "Management" it is possible to review, change or delete the created records, pages or headings, and also to work with comments of visitors.

The section "Links" allows to manage references which are contained on the homepage. References in this section can be added, deleted, changed, added the description, to create sections of links.

If you want to edit appearance of a template of the website - come into the section "Appearance". In this section you can use "That editor". And if you want to establish a ready subject of registration, then you can copy files of a subject in wp directory - content/themes and in division of "Subject" to select the copied subject.

The section "Plug-ins" allows to install in Wordpress plug-ins - additional files which add functionality. For installation of a plag_ $n$ just it is necessary to copy its file in the wp folder content/plugins. In the section "Users" the site administrator can manage accounting records of users of the website: to add new users, authors, to change their data or to delete accounting records.

In the section "Setup" it is possible to perform various tunings of the Wordpress system. In this section it is possible to configure the access level of users, to configure actions of system in response to actions of visitors, to create the name and the description of the Internet shop, an arrangement of directories and a lot of things another. The content management system of Wordpress has several advantages:

- it allows to carry out the instant publication of records;

- is free;

- it provides management of pages;

- it gives an opportunity to password protection of pages and posts;

- in Wordpress the integrated tape of friendly blogs;

- the established protection against spam in comments;

- it simple in installation, it is easy to update or modify it;

- it it is possible to administer several authors;

- in Wordpress PHP and MySQL are used;

- easy setup віджетів;

- the built-in editor of the HTML pages has;

- automatic adding the corresponding menu items after creation of new publications in appropriate sections;

- has an opportunity to carry the publication to several categories;

- has the open code.

Of course, the most important benefit of WordPress which allowed to win wide popularity - its free of charge. That is everyone who wanted create the own website could make without excess expenses and attachments it by means of WordPress. There is a huge number of other free engines, but WordPress subdued all the simplicity of establishment, setup and use. Everything is extremely clear and available.

It is possible to add content on the website by means of the visual editor who is not more difficult to the interface in Word. Adm_n-panel it is intuitively clear to all and everyone, it is possible to master it for very short time. To expand functionality of the website, it is enough to install necessary plug-ins.

Most of them as well as templates, are in free access. If it is necessary to make changes to reflection, style or structure of the website, it can be made, koreguyuch a code in files of a subject. Structure of the WordPress template, hierarchy of its files also relatively simple, in comparison with CMS Joomla.

Besides, thanks to the popularity, at forums and the specialized websites you will be able to find answers to all possible questions on work with given by the engine. Also thanks to work of developers and simple installation of official updates of system, the websites on WordPress are adequately protected from infections. And vulnerabilities that arise, rather quickly are eliminated. WordPress usually has also shortcomings, especially it is worth selecting the following: 
- rather powerful load of the server;

- occasionally low speed of loading of the website;

- limited set of basic functions;

- duplications of pages and images;

- a large number of low-quality subjects and additions with errors;

- relative mistrust of search engines to the websites on free engines.

The WordPress engine, and especially large number of additions to it can significantly load the server on which the website is located. In order to avoid excessive loading it is necessary to reduce quantity of the installed plug-ins to a necessary minimum. Besides, it is important to place the blog on a qualitative hosting. These options will help to increase the speed of loading of the website also. Also, for acceleration of work of the website it is necessary to optimize the database and to use a plug-in for a caching of pages.

One of shortcomings of WordPress is the fact that it automatically generates doubles of pages. Also the engine of Vordpress when loading pictures creates their copies of the different sizes. For removal of unnecessary pictures it is possible to use a plug-in of DNUI (Deletenotusedimage).

It is also desirable to use the checked additions that your website worked regularly and without errors. And before installation of a template, it is necessary to check its plug-in TAC.

Popularity of WordPress - its advantage and a shortcoming at the same time. Search engines belong watchfully to the young websites on WordPress and on other free CMS.

At first possibilities of a resource are limited to feature set which are mortgaged in a basis of the engine and the established template. For expansion of opportunities it is possible to use plug-ins, however, their large number can affect the speed of work of the website. In this case it is possible to make in addition changes to files of a template, to add new functions by means of editing a code. However, the corresponding skills, or services of the specialist for this purpose will be necessary. Therefore it is important to define at first the purposes, a type, structure and necessary opportunities for the resource. Depending on it to select the most suitable management systems with optimum feature set.

It is necessary to consider more in details further HTML because work with it will be the following step.

At first the speech of HTML was conceived and created as means of structurization and formatting of documents without their binding to means of a reconstruction (reflection). Ideally, the text with a marking of HTML had to be recreated without stylistic and structural distortions on the equipment with different technical equipment (the color screen of the modern computer, the monochrome screen of an organizer limited behind the sizes the screen of the mobile phone or the device and the program of a voice reconstruction of texts). However the modern HTML application very in the distance from its initial task. For example, the tag $<$ table $>$ is intended for creation in documents of tables, but is sometimes used also for registration of placement of elements on the page.
Eventually the main idea a platformozavisimost of the HTML language was sacrificed to the modern needs for multimedia and graphic design. HTML - a tag markup language of documents. Any document in the HTML language is item collection, and the beginning and the end of each element is designated by special marks - tags. Elements can be empty, that is do not contain any text and other data (for example, a tag of a rupture of the lines $<$ br $>$ ). In this case the closing tag usually is not specified. Besides, elements can have attributes which define any their properties (for example, type size for a tag $<$ font $>$ ). Attributes are specified in a tag which opens.

Proceeding from this information, it is possible to note that the HTML language it is extremely necessary for development for nterent-shop.

The database which will contain goods, their description and another it is necessary to administer.

phpMyAdmin - web addition with the open code in the PHP language with a graphic web interface for administration of the MySQL or MariaDB database. PhpMyAdmin allows to carry out administration of the MySQL server via the browser, to start SQL requests, to review and edit contents of tables of databases.

This program enjoys wide popularity at web developers as allows to direct the MySQL database without input of the SQL teams via the friendly interface and from any computer connected to the Internet without the need for establishment of the additional software.

Today phpMyAdmin is widely put into practice. The last is connected with the fact that developers intensively develop the product, considering all innovations of SKBD MySQL. The vast majority of the Ukrainian providers use this zastosunok as a control bar to give to the clients an opportunity of administration of the databases selected with it.

The program is distributed under the license GNU GeneralPublicLicense and therefore some other developers integrate it into the developments, for example XAMPP, Denwer.

MySQL - a free relational database management system. MySQL was developed by the TsH company for speeding up of processing of big databases. This database management system (SKBD) with the open code was created as an alternative to commercial systems. MySQL from the very beginning was very similar to $\mathrm{mSQL}$, however over time it all extended and now MySQL - one of the most widespread database management systems. It is used, first of all, for creation of dynamic web pages as has wonderful support from various as if programming.

SCO OpenServer (before SCO UNIX and SCO OpenDesktop) - the version of the Unix operating system closed source developed by the SantaCruzOperationruen (SCO) company also extends SCO Group.

SCO OpenServer 5, operating system on the basis of UNIX System V Release 3, was for the first time released by SantaCruzOperation in 1992. SCO Open Server 5 by this time continues to be supported by SCO.

SCO OpenServer 6, operating system on the basis of UNIX System V Release $4.2 \mathrm{mp}$, was released by SCOGroup in 2005. In it were added the support of big 
files, memories a lot of flowing kernels. SCO OpenServer 6 contains the kernel of UnixWare 7 SVR5 integrated with additions and the priznacheena for use of the OpenServer environment. Open Server is the portable server platform and software environment created especially for web developers taking into account their recommendations and wishes.

The program complex has the rich set of the server software, convenient, the multifunction thought-over interface, has powerful opportunities from administration and setup of components. The platform is widely used for the purpose of development, adjustment and testing of web projects, and also for providing web services on the local area networks.

hough at first software products which are a part of a complex were not developed especially for work the friend from the friend, such sheaf became very popular among users of Windows, first of all because they received a free complex of programs with reliability at the level of Linux of servers. Open Server - the reliable tool is necessary for each web master.

Summarizing: for creation of the Internet shop it is possible to use WordPress as a content management system, HTML for a marking of the hypertext page, PhpMyAdmin for administration of SKBD MySQL.

\section{Conclusion}

The correct use of the considered method and the selected software allow to create competitive Internet shop with the minimum sentries and material costs. what will be convenient for its administration both visually attractive and intuitively clear to users.

\title{
REFERENCES
}

1. WordPress, available at: https://uk.wikipedia.org/wiki/WordPress.

2. HTML, available at: https://uk.wikipedia.org/wiki/HTML.

3. Benefits of useWordpress, available at: $\mathrm{https}$ ://inneti.com.ua/it/it-posluhy/perevahy-korystuvannya-wordpress/

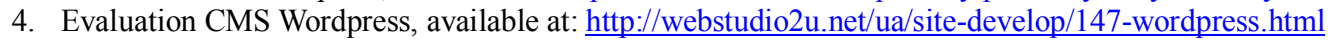

5. PhpMyAdmin, available at: https://uk.wikipedia.org/wiki/PhpMyAdmin.

6. SCO OpenServer, available at: https://ru.wikipedia.org/wiki/SCO_OpenServer.

7. Kuchuk G., Kharchenko V., Kovalenko A., Ruchkov E. Approaches to selection of combinatorial algorithm for optimization in network traffic control of safety-critical systems. East-West Design \& Test Symposium (EWDTS). 2016. Pp. 1-6. doi:https://doi.org/10.1109/EWDTS.2016.7807655.

8. MySQL, available at: https://uk.wikipedia.org/wiki/MySQL.

\author{
Рецензент: д-р техн. наук, проф. О. В. Шульга, \\ Полтавський національний технічний університет імені Юрія Кондратюка, Полтава \\ Received (Надійшла) 04.04.2018 \\ Accepted for publication (Прийнята до друку) 30.05.2018
}

\section{Якісний вибір програмних засобів для побудови сервісу з продажу електронної техніки}

\author{
Н. В. Ічанська, Ю. Г. Подошвелев, О. В. Смицький, К. А. Рибаченко
}

Предметом вивчення в статті є пояснення методу вибору програмних засобів та приклад їх використання для створення електронного магазину, основи створення простого у користуванні і методи уникнення явних недоліків таких сервісів. Результати - акцентовано увагу на якісний вибір програмних засобів від яких залежить зручність створюваного сервісу, а саме: системи керування вмістом сайту, мови гіпертекстової розмітки, системи керування базами даних. Розглянуто найбільш вживані та продуктивні програмні засоби та пояснено їх переваги і недоліки, показано як правильний вибір програмних засобів впливає на гнучкість розробки на прикладі. Подано алгоритм створення інтернет-магазину. Описано основні проблеми, які можуть виникати при створенні панелі керування вмістом для адміністратора та при користуванні сервісом для потенційних покупців. Запропоновано варіант подолання цих проблем шляхом використання системи керування вмістом WordPress та побудови лінійного користування сайтом. Висновок - метод дозволяе забезпечити конкуруючі можливості в адмініструванні сервісу, в гнучкості та простоті його розробки, раціональному виборі використовуваних ресурсів і методів, при цьому не створюючи окрему адміністраторську панель для керування наповненням інтернет-магазину.

Ключов і слов а: програмні засоби, інтернет-магазин, система керування вмістом, WordPress, бази даних, мова гіпертекстової розмітки, система керування базами даних, конкурентоздатність, методи розробки.

\section{Качественный выбор программных средств для построения сервиса по продаже электронной техники}

\section{Н. В. Ичанская, Ю. Г. Подошвелев, О. В. Смицкий, К. А. Рыбаченко}

Предметом изучения в статье есть объяснение метода выбора программных средств и пример их использования для создания электронного магазина, основы создания простого в использовании и методы избежания явных недостатков таких сервисов. Результаты - акцентировано внимание на качественный выбор программных средств от которых зависит удобство создаваемого сервиса, а именно: системы управления содержимым сайта, языка гипертекстовой разметки, системы управления базами данных. Рассмотрены наиболее употребительные и производительные программные средства и объяснено их преимущества и недостатки, показано как правильный выбор программных средств влияет на гибкость разработки на примере. Представлен алгоритм создания интернет-магазина. Описаны основные проблемы, которые могут возникать при создании панели управления содержанием для администратора и при пользовании сервисом для потенциальных покупателей. Предложен вариант преодоления этих проблем путем использования системы управления содержимым WordPress и построения линейного пользования сайтом. Вывод - метод позволяет обеспечить конкурирующие возможности в администрировании сервиса, в гибкости и простоте его разработки, рациональном выборе используемых ресурсов и методов, при этом не создавая отдельную администраторскую панель для управления наполнением интернет-магазина.

Ключевые слова : программные средства, интернет-магазин, система управления содержимым, WordPress, базы данных, язык гипертекстовой разметки, система управления базами данных, конкурентоспособность, методы разработки. 